\title{
Infectious pacemaker exteriorisation
}

\author{
Uday Yanamandra, ${ }^{1}$ Sushma Yanamandra, ${ }^{2}$ Navreet Singh ${ }^{3}$ Velu Nair ${ }^{4}$
}

${ }^{1}$ Department of Internal Medicine, Armed Forces Medical College, Pune,

Maharashtra, India ${ }^{2}$ Department of Medicine, CAIMS, Karimnagar, Andhra Pradesh, India

${ }^{3}$ Department of Cardiology, Army Hospital Research \& Referral, New Delhi, India

${ }^{4}$ Armed Forces Medical

College, Pune, Maharashtra, India

\section{Correspondence to} Dr Uday Yanamandra, udayj2@gmail.com

\section{CrossMark}

\section{To cite: Yanamandra $U$,} Yanamandra S, Singh N, et al. BMJ Case Rep Published online: [please include Day Month Year] doi:10.1136/bcr-2013202893

\section{DESCRIPTION}

A 68-year-old man who 1 year previously had been fitted with a permanent pacemaker implantation (PPI) for symptomatic sinus bradycardia was admitted with recurrent syncope and intermittent moderate-grade fever for 2 months. He was on intermittent antibiotics from rural health centre for the same duration with no improvement in his condition.

On examination, he was frail with exteriorisation of the pacemaker (figure 1) with pus exuding from the pacemaker pocket. Transoesophageal echocardiography revealed subvalvular vegetation suggestive of subacute bacterial endocarditis (SBE). All other haematological and biochemical parameters were normal. Pus culture from the pocket revealed Gram-positive cocci in groups sensitive to $\beta$-lactams and vancomycin. Repeated blood cultures were sterile. He was managed with removal of pacemaker/leads, management of SBE with antibiotics (vancomycin with ceftriaxone) for 3 weeks, transient glycopyrrolate/external pacemaker management and replacement of pacemaker on a later date on opposite side.

Pacemaker pocket erosion caused by generator is usually a result of pocket infection which later leads to exteriorisation of the pacemaker. It is a rare complication of PPI (incidence <1\%) commonly seen in elderly patients with decreased subcutaneous fat/fragile skin, PPI in a small pocket, use of harsh/strong disinfectants with increased scrubbing and prolonged steroid intake. Exteriorisation obligates intense antibiotics therapy and removal of the pacemaker owing to bacterial contamination and its intravascular/intracardiac spread through pacemaker leads. ${ }^{2}$

Prophylactic anti-staphylococcal antibiotic treatment during implantation may prevent not only PPI infections but also pacemaker exteriorisation linked to hidden infections. ${ }^{3}$

\section{Learning points}

Pacemaker exteriorisation is commonly an aftermath of implantation site infection.

- Infection can spread through the leads of exteriorised pacemaker to blood stream.

- Immediate removal of the device is essential in such cases.

Acknowledgements We would like to thank the O/o DGAFMS for all the cooperation.

Contributors All authors were involved in managing and preparing the manuscript.

\section{Competing interests None.}

Patient consent Obtained.

Provenance and peer review Not commissioned; externally peer reviewed. 


\section{REFERENCES}

1 Kabayadondo MG, de Meester A. Early complications after pacemaker implantations, cardiac pacemakers-biological aspects, clinical applications and possible complications, Edited by Mart M; 2011:161-80. InTech, doi:10.5772/ 20091. Available from: http://www.intechopen.com/books/cardiac-pacemakersbiological-aspects-clinical-applications-and possible-complications/ early-complications-after-pacemaker-implantations. ISBN 978-953-307-639-3.

2 Bru $\mathrm{P}$, Cointe $\mathrm{R}$, Metge $\mathrm{M}$, et al. Value of systematic preventive antibiotherapy in cardiac pacemaker implantation. Ann Cardiol Angeiol (Paris) 1991;40:171-4.

3 Klug $D$, Wallet $F$, Lacroix $D$, et al. Local symptoms at the site of pacemaker implantation indicate latent systemic infection. Heart 2004;90:882-6.

Copyright 2014 BMJ Publishing Group. All rights reserved. For permission to reuse any of this content visit

http://group.bmj.com/group/rights-licensing/permissions.

BMJ Case Report Fellows may re-use this article for personal use and teaching without any further permission.

Become a Fellow of BMJ Case Reports today and you can:

- Submit as many cases as you like

- Enjoy fast sympathetic peer review and rapid publication of accepted articles

- Access all the published articles

- Re-use any of the published material for personal use and teaching without further permission

For information on Institutional Fellowships contact consortiasales@bmjgroup.com

Visit casereports.bmj.com for more articles like this and to become a Fellow 